\title{
PERAN KEKERABATAN DALAM PEMENAGAN PEMILIHAN KEPALA DESA MENJALIN TAHUN 2018
}

\author{
Kur Junaidi \\ Fakultas IImu Sosial dan IImu Politik Universitas PGRI Palangka Raya \\ (email: wijikolestariono@gmail.com) \\ Tuti Lestari \\ Fakultas IImu Sosial dan IImu Politik Universitas PGRI Palangka Raya
}

\begin{abstract}
Abstrak
Tujuan penelitian yang pertama untuk mengetahui bagaimana bentuk politik kekerabatan Desa Menjalin mencakup wilayah kerabat, pengamatan, dan praktek kehidupan bersama dalam lingkup politik desa.Kedua untuk mengetahui peran dan upaya kerabat dalam Pemilihan Kepala Desa 2018. Penelitian ini menggunakan pendekatan kualitatif dengan jenis Field research. Adapun teknik pengumpulan data yang digunakan penelitian ini adalah observasi, in dept interview (wawancara mendalam) dan dokumentasi. Sedangkan teknik analisis data dalam penelitian ini menggunakan analisa data kualitatif meliputi reduksi data, display data, verifikasi dan simpulan. Teknik pemeriksaan keabsahan yang digunakan adalah trianggulasi, sedangkan teori yang digunakan adalah antropologi politik, konsep kekuasaan.

Hasil Penelitian: a) kekerabatan yang terdapat dalam Desa Menjalin keluarga yang luas dari keturunan ayah atau ibu atau disebut bilateral juga bisa dikatakan kekerabatan kindred dimana kesatuan kerabat yang melakukan interaksi atau berkumpul antar anggota kerabat pada waktu tertentu. Dalam kehidupan politik memang sudah terjadi pengkaderan dari saudara-saudara yang lebih terdahulu memimpin meskipun tidak terlihat secara masif namun sudah disiapkan untuk memimpin Desa Menjalin selanjutya. b) Peran kerabat dalam hal ini sudah sangatlah jelas, jika sudah ada pengkaderan maka tugas kerabat yang lain pastinya gerakannya yakni menjadi tim sukses yakni mempengaruhi tetangga sekitar untuk memilih nama kerabat yang diusung dan memastikan kerabat yang diusung berhasil menduduki Menjalin satu.
\end{abstract}

\section{Kata kunci : Politik Kekerabatan, Desa Dan Kekuasaan}

\section{Pendahuluan}

Dalam sistem Pemerintahan Indonesia, desa merupakan bagian pemerintahan paling dasar. Desa merupakan asset dalam negara sehingga pengelolahannya harus sebisa mungkin menghasilkan peningkatan kualitas, namun dalam realitas terjadi dilapangan sering terjadi kesalahan kewenangan dalam implementasi hal tersebut. Tidak 
hanya disitu saja anomali ataupun ketimpangan juga banyak dilakukan oleh beberapa Aparatur desa, bahkan terjadi distorsi dalam menyelenggarakan kewenangan dan tugas dalam pemimpin desa.

Berbicara tentang Pemilhan Pemimpin Desa atau Pilkades adalah suatu Pemilihan Kepala Desa untuk mencari pemimpin terbaik yang nantinya mempunyai kekuasaan dan wewenang untuk mengendalikan pembangunan desa selama calon terpilih sebagai Kepala Desa yang mengedepankan asas langsung, umum, bebas, dan rahasia oleh warga setempat. (Ananda Santoso, 2000) Pilkades merupakan salah satu kegiatan politik yang menarik bagi masyarakat desa. Pilkades di Indonesia saat ini masih penuh dengan ironisme. Di satu sisi, rakyat yang sangat apatis dan tidak peduli sehingga tingkat partisipatif masyarakat dalam Pilkades menurun. Apatis masyarakat ini justru dimanfaatkan oleh orang-orang tertentu untuk meraih jabatan dan kekayaan dengan memanfaatkan kekuasaan politik. Mereka adalah para elit desa yang ingin melanggengkan kekayaan dan kekuasaan agar tetap jatuh kepada garis keluarga. Sehingga fakta menunjukan keberadaan Calon Kepala Desa masih didominasi oleh segelintir orang yang berkuasa dari golongan desa.

Kekuasaan, modal materi, dan modal sosial pada dasarnya sebagai alat untuk meraih kemenangan. Disini Calon Kepala Desa memainkan sumber kekuasaan untuk memperoleh dukungan sebanyak-banyaknya. Dalam prakteknya Calon Kepala Desa membutuhkan sebuah cara yang efektif. Melalui pertimbanganpertimbangan yang matang seperti membuat rancangan strategi sampai pada memanfaatkan ikatan keluarga sebagai tim sukses untuk melanggengkan kekuasaan, sumber kekuasaan itu diharapkan dapat menarik dukungan yang lebih besar pula.

Fenomena majunya Calon Kepala Desa yang mempunyai hubungan keluarga dengan pejabat sebelumnya, bahkan banyak dari warganya yang merupakan kerabat sebenarnya sangat ironis. Hal ini menunjukan bahwa kursi Kepala Desa adalah jabatan yang menguntungkan, membawa berkah, dan bisa dijadikan sarana untuk mengumpulkan kekayaan serta melanggengkan kekuasaan untuk diturunkan kepada keluarga maupun kerabat sendiri. Pilihan regenerasi model kekerabatan seperti ini jelas merupakan cermin bahwasannya masyarakat desa masih mempraktekan model demokrasi tradisional yang hanya percaya pada kemampuan yang dimiliki calon-calon yang masih memiliki hubungan keluarga dengan pemimpin terdahulu. (Hasil wawancara pak Amat) Model ini mirip dengan praktek politik patrimonial. Karena kepercayaan ini maka penyerahan mandat atau jabatan kepemimpinan di desa hanya akan berputar disekitar lingkaran kerabat yang memiliki garis karir politik dan kekuasaan. Calon yang mempunyai hubungan keluarga dengan orang-orang berpengaruh di daerahnya pasti akan lebih diuntungkan dari pada calon lain. Orangorang berpengaruh itulah yang kemudian disebut elit desa.

Dalam Kajian Antropologi Politik Kekerabatan, politik kekerabatan sanggup dan bertahan menghadapi evolusi politik.Antropologi mempercayai politik kekerabatan akan menjadi dominan. Pada dasarnya budaya politik kekerabatan memunculkan banyak pro dan kontra. Sebagian ada yang menganggap baik karena kestabilan politik terjaga dan sebagian pula ada yang menganggap

\section{Jurnal Sociopolitico}


bahwa politik kekerabatan hanya alat yang digunakan para pejabat untuk melanggengkan kekuasaannya. Selain itu politik kekerabatan mempersempit kesempatan bagi orang lain yang berpartisipasi lebih untuk menjadi Kepala Daerah karena biasanya calon pemimpin dari politik kekerabatan lebih banyak dukungan.

Menjamurnya politik kekerabatan khususnya di desa-desa merupakan bukti nyata bahwa demokrasi tidak berjalan dengan baik, realitasnya banyak sekali Calon-calon Kepala Desa yang kualitasnya dibawah standarisasi akan tetapi bisa menduduki jabatan Kepala Desa yang strategis. Ternyata adanya demokrasi tidak menyehatkan rakyat, tidak membuat masyarakat terdidik, justru sistem demokrasi itu disalah gunakan atau dicederai oleh oknum-oknum atau masyarakat yang undemkratik. Maksudnya sistem demokrasi sudah benar akan tetapi sistem demokrasi diterapkan kepada orang yang belum paham tentang apa hakikat demokrasi, maka demokrasi tersebut berarti demokrasi lipstik yang artinya demokrasi yang hanya di bibir saja akan tetapi implementasinya masih kerajaan atau otokrasi. Sehingga yang disalahkan bukan sistemnya, tetapi orang yang harus ditingkatkan pemahamannya tentang demokrasi.

Berdasarkan fakta tabel diatas menunjukan peran kerabat sangatlah penting dalam setiap kemenangan. Pemilihan pemerintah desa yakni Pilkades Desa Menjalin masih dikuasai oleh segelintir elit desa bahkan bahkan pemimpin terdahulu sampai sekarang masih mempunyai ikatan keluarga. Fakta lainya yang ditemukan oleh peneliti yakni $60 \%$ dari warganya masih terikat kerabat dengan Kepala Desa sehingga memperkecil kesempatan pesaing untuk menang dalam Pilihan Kepala Desa. Berdasarkan fakta-fakta diatas penelitian ini menarik untuk di tulis.

\section{Metode Penelitian}

Penelitian ini menggunakan pendekatan kualitatif yakni data yang digunakan merupakan data kualitatif (data yang tidak terdiri dari angka-angka) melainkan berupa gambaran dan kata-kata. (Jalaludin Rahmat, 2000) Adapun secara terminologi pendekatan kualitatif adalah metode yang mana hasil penelitian lebih berkenaan dengan interprestasi terhadap data yang ditemukan di lapangan. (Sugiono, 2010). Penelitian kualitatif juga dapat diartikan sebagai penelitian yang memiliki tujuan untuk memahami fenomena tentang sesuatu yang dialami oleh obyek penelitian secara holistik, dan di deskripsikan dengan bentuk kata-kata dan bahasa. Pada konteks khusus yang natural dengan menggunakan metode ilmiah. (Lexy J.Moleong, 2007). Sedangkan jenis penelitian ini adalah jenis case study, artinya penelitian ini berangkat dari studi kasus lapangan yang bertujuan untuk memperoleh data yang relevan.

\section{Hasil dan Pembahasan Politik Kekerabatan Desa Manjalin}

Pemilihan Kepala Desa atau seringkali disebut Pilkades adalah suatu Pemilihan Kepala Desa untuk mencari pemimpin terbaik yang nantinya mempunyai kekuasaan dan wewenang untuk mengendalikan pembangunan desa selama beliau terpilih sebagai Kepala Desa yang mengedepankan asas langsung, umum, bebas, dan rahasia oleh warga desa

\section{Jurnal Sociopolitico}


setempat. (Ananda Santoso, 2000) Berbalik dengan penjelasan diatas, realita yang terjadi di lapangan dalam Pemilihan Kepala Desa di Desa Manjalin meskipun langsung, umum, bebas dan rahasia. Ternyata terdapat rahasia yakni dari era kolonial sampai sekarang masih dipegang oleh satu keturunan atau satu keluarga yang ada hubungan darah.

Politik kekerabatan dalam bahasa sederhana dapat diartikan sebagai sebuah rezim kekuasaan politik atau aktor politik yang dijalankan secara turun-temurun atau dilakukan oleh satu keluarga ataupun kerabat dekat. Pada dasarnya politik kekerabatan memunculkan pro dan kontra. Sebagian ada yang menganggap baik karena kestabilan politik terjaga dan sebagian pula ada yang menganggap politik kekerabatan hanyalah alat yang digunakan para pejabat untuk mempertahankan kekuasaannya. Selain itu politik kekerabatan mempersempit kesempatan bagi orang lain berpartisipasi lebih untuk menjadi kepala daerah atau Kepala Desa karena biasanya calon pemimpin hasil dari politik dinasti lebih banyak dukungan. (Dr. Yatim, Badri, 1993)

Seperti kita ketahui bahwasannya politik kekerabatan rentan dengan yang namanya KKN Korupsi, Kolusi, dan Nepotisme terutama dalam tingkat desa. Pada umumnya posisi kajian mengenai isu dinasti politik ini berada dalam konteks perbincangan mengenai politik kekerabatan (keluarga) sebagaimana dapat dibaca dalam cara bagaimana para ahli itu mendefinisikan dinasti politik. Pablo Querubin mendefinisikan dinasti politik sebagai sejumlah kecil keluarga yang mendominasi distribusi kekuasaan dalam area geografis tertentu. Mark R. Thompson menjelaskan dinasti politik hanya sebagai jenis lain dari transisi (peralihan) kekuasaan politik, langsung maupun tidak langsung, yang melibatkan anggota keluarga. Hal ini diperkuat dengan hasil wawancara dengan Bapak Adul Tokoh Masyarakat.

" Politik kekerabatan suatu jabatan politik yang diserahkan secara turun temurun dalam lingkup keluarga. Saya aslinya orang parenggean pada tahun 1980 ada Pemilihan Kepala Desa tapi ternyata di Desa Menjalin berbeda dengan umumnya dimana calon Kepala Desa masih kerabat Kepala Desa sebelumnya dan Pemilihnya atau warganya kerabat semua"

Dari hasil wawancara dengan Mr. $\mathrm{X}$ peneliti bisa menyimpulkan Pilkades yang terjadi di Desa Menjalin berbeda dengan Pilkades desa-desa lain. Sudah menjadi rahasia umum Desa Menjalin memanfaatkan kekerabatan yang termasuk elit desa demi kemenangan jabatan kepala desa. Dengan Mr. X, peneliti mendapatkan banyak informasi penting seperti ulasan diatas $1 \mathrm{RW}$ terdapat 100 kartu keluarga bisa lebih, setiap satu kartu keluarga ada 3 atau 4 orang yang berhak memilih bisa di simpulkan $1 \mathrm{RW}$ memberikan kurang lebih 350 suara sah dari kerabat.

Antara teori dengan hasil wawancara dapat diambil sebuah kesimpulan bahwasannya politik kekerabatan atau yang lebih sering disebut politik dinasti itu suatu jabatan politik yang diturunkan secara turun temurun dalam ruang lingkup keluarga. Politik kekerabatan memanfaatkan senior atau pemimpin terdahulu menjadi patokan untuk memimpin di tahun selanjutnya. Sebenarnya kalau kita berkaca atau mengikuti aturan yang kita anut, sistem di

\section{Jurnal Sociopolitico}


Indonesia termasuk dalam sistem demokrasi, jadi sebenarnya politik kekerabatan tidak diperbolehkan di negara kita.

Politik kekerabatan yakni dimana sesuatu kekuasaan yang tidak hanya turun temurun dipegang dan dipertahankan oleh keluarga tapi tali persaudaraan diikat oleh satu garis keturunan marga atau nasab dari banyak keluarga sehingga dimana semua kerabat atau keluarga turut menerima keberhasilan dari salah satu keluarga yang meraih. Tidak dipungkiri adanya keluarga yang berhasil meraih kekuasaan dalam suatu daerah maka secara otomatis kerabat menjadi elit dikalangan daerah tersebut. Indonesia khususnya tidak lagi menganut sistem monarki atau sistem kerajaan yang bisa mengambil alih kekuasaan secara turuntemurun dan kekeluargaan. Namun realita yang terjadi demokrasi masih jauh dari kata sempurna untuk mengambil alih kekuasaan terkesan dari undang-undang, peraturan pemerintah, maupun tata tertib pemilihan yang menjadi landasan pelaksanaanya hanyalah sebatas aturan formal penuh kelemahan dan tidak menjamin rekrutmen politik yang demokratis, obyektif dan rasional. Karena jika kita melihat dari beberapa kasus yang mana kekuasaan di daerah terkesan di atur dan di setting untuk beberapa elit saja. Berikut salah satu pemaparan tokoh agama tentang bentuk kekerabatan Desa Menjalin:

"kemenangan kades dalam pemilihan tidaklah lepas dari peran sanak keluarga, salah benar pastinya tetep keluarga." (Hasil Wawancara dengan Suni tokoh agama)
Jauh dari memandang kekerabatan dan kekuasaan itu sebagai pengertian yang saling meniadakan, antropologi politik telah memperlihatkan ikatan-ikatan kompleks antara dua sistem itu, menganalisanya, serta menghubungkan teori-teori mengenai hubungan-hubungan itu dengan berlandaskan kepada karya lapangan. Meskipun demikian, tidaklah mudah untuk membedakan antara hubungan kekerabatan dan kekuasaan dengan menimbang begitu eratnya hubungan antara keduanya. Dibanyak masyarakat- masyarakat primitif misalnya banyak ditemui adanya kekuasaan yang selalu disandingkan dengan kekerabatan. Hal ini dapat dilihat dari kreteria masyarakat primitif khususnya dalam keanggotaan suatu komunitas politik. Seperti halnya metode keturunan baik dari garis keturunan patrineal maupun matrilineal terutama mengkondisikan kewarnegaraan dalam masyarakatmasyarakatnya serta didasarkan atas hubungan-hubungan dan kelompokkelompok yang disusunnya secara tajam yang akan berbeda dengan kekerabatan dalam pengertian ketetapannya. Sedangkan dalam masyarakat segmenter yang menarik sebuah sistem perbudakan domestik, status para budaknya didefinisikan terutama dalam pengertian pengucilan dari sebuah garis keturunan dan mengambil bagian sebagai kontrol atas kehidupan masyarakat. (Geoges Balander, 1996) Kekerabatan adalah unitunit sosial yang terdiri dari beberapa keluarga yang memiliki hubungan darah atau hubungan perkawinan. (Menurut Chony dalam Ali Imron, 2005) Sistem kekerabatan dijelaskan bukan hanya saja didasarkan karena adanya hubungan perkawinan atau karena adanya hubungan keluarga tetapi karena adanya hubungan

\section{Jurnal Sociopolitico}


darah. Selain itu juga menyebutkan bahwa kunci pokok sistem perkawinan bukan karena hubungan darah melainkan juga berasal dari kelompok keturunan (liniage) atau garis keturunan (descent). Antara anggota kelompok keturunan saling berhubungan karena memiliki nenek moyang yang sama dan kelompok kekerabatan ini bersifat patrilineal atau matrilineal.

\section{Peran Kerabat Dalam Pemenagan Pilkades}

Kekerabatan adalah unit-unit sosial yang terdiri dari beberapa keluarga yang memiliki hubungan darah atau hubungan perkawinan. Sistem kekerabatan dijelaskan bukan hanya saja didasarkan karena adanya hubungan perkawinan atau karena adanya hubungan keluarga tetapi karena adanya hubungan darah. Selain itu juga menyebutkan bahwa kunci pokok sistem perkawinan bukan karena hubungan darah melainkan juga berasal dari kelompok keturunan (liniage) atau garis keturunan (descent). Antara anggota kelompok keturunan saling berhubungan karena memiliki nenek moyang yang sama dan kelompok kekerabatan ini bersifat patrilineal atau matrilineal. Berikut wawancara dengan salah satu kerabat beliau mengenai peran kerabat dalam Pilkades:

"Desa Menjalin dari dulu rata-rata calon Kadesnya masih berbau saudara..., herannya lagi yang milih ya saudara-saudara sendiri" (hasil wawancara dengan Ridwan)

Seperti informasi yang saya dapatkan yakni para Calon Kepala Desa, serta Pemilihnya adalah mayoritas kerabatnya tidaklah heran apabila politik kekerabatan akan menjadi dominan.
Dimana Desa Menjalin mempunyai orang yang berpengaruh atau merasa lebih mampu dalam hal kepemimpinan mereka tidak mampu mengalahkan gerakkan massa elit kekerabatan kades terpilih. Berikut ini kelanjutan wawancara dengan warga Menjalin;

"disini mayoritas kerabat bp kades, bahkan sederet gang ini adalah sanak, ponakan, misanan dan ratarata saudara, serta kerabat kades." (hasil wawancara dengan Andi)

Dalam kajian pustaka, Nur Holifa, Skripsi, Politik Dinasti Samidin, Sampang Madura terdapat temuan bahwasannya keturunan Kepala Desa dari generasi ke generasi selanjutnya terkait adanya strategi mengikat masyarakat seperti cara rentenair, dalam temuannya terdapat Kepala Desa pendahulu yang memberikan hutangan berupa uang, emas, pupuk, hewan ternak terhadap warga. Secara tidak langsung warga terikat dan tidak bisa lepas dari Kepala Desa tersebut.

Berbeda informasi wawancara yang didapat penulis memberikan fakta bahwasannya kerabat dari penguasa pasti menjadi golongan elit desa. Dan mereka juga menjadi profesi yang disegani masyarakat sekitar. Sesuai dalam penjelasan sebelumnya kekerabatan yang ada di Desa Menjalin tidak hanya sebatas pergantian kekerabatan dalam memimpin desa.

Dalam Pilkades 2019 peran kekerabatan biasanya selalu berdampingan dengan kekuasaan sehingga kekuasaan dipandang sebagai suatu gejala yang selalu terdapat dalam proses politik, namun para ilmuan politik tidak ada yang sepakat mengenai perumusan pengertian kekuasaan. Bahkan beberapa diantaranya menyarankan agar konsep kekuasaan

\section{Jurnal Sociopolitico}


ditinggalkan dengan alasan bersifat kabur dan selalu berkonotasi emosional. Namun tampaknya politik tanpa kekuasaan apalagi sekarang fenomena politik kekerabatan ibarat agama tanpa moral. Karena modern ini banyak para aktor politik yang selalu melibatkan keluarganya untuk berkecimbung juga dalam dunia politik hal ini terlihat diberbagai daerah menjelang Pemilihan kepala daerah yang serentak dilakukan pada akhir-akhir ini.Berikut ini adalah hasil peneliti wawancara dengan warga Menjalin penilaian terhadap Calon Kades, penjelasan salah satu tokoh masyarakat Menjalin tengah:

"Di Desa Menjalin memang mayoritas kerabat Calon Kades, jadi semacam mempunyai dinasti dan jika ada pemilihan kekerabatan difungsikan sebagai tim sukses dengan kata lain mengajak tetangganya memilih Calon Kades"

Dari penjelasan warga yang menyatakan tegas, baik, banyak programnya peneliti setuju dengan pernyataan tersebut, namun dalam hasil penelitian jika dilihat dari hasil wawancara sebelumnya Programnya tersebut melanjutkan program terdahulu, bahkan masih sering terlibat maka gugur pernyataan di atas. Jika dilihat dari birokrasi kita bisa mengetahui bahwasanya kepemimpin tanpa adanya Sekertaris Desa, kerabat adik ipar memegang kendali atas Bendahara dan Kasi Pembangunan adapun bagian Kasi Umum juga dipegang kerabat. Maka bisa disimpulkan gaya kepemimpinan bebas atau Laissez Faire dimana pemimpin tidak memimpin atau mengendalikan bawahannya sepenuhnya, tidak ikut serta dengan bawahannya. Dalam teori politik kekerabatan model seperti ini sering ditemukan karena demi berlangsungnya roda pemerintahan dan ketengan dalam desa. Adapun kutipan wawancara dengan salah satu tokoh agama Menjalin:

"di Menjalin memang orangnya baik, banyak sekali programnya. Kades terpilih meneruskan program kades terdahulu."

Peneliti menyimpulkan benar dari data orang yang memberikan informasi pertama yakni dimana setiap ada pemilu kerabat digerakkan dan membuat tangan kekuasaan harus dipimpin garis keturunannya.

Tidak menutupi kemungkinan bahwasaanya suatu tingkatan wilayah desa masih menggunakan peran kekerabatan dalam seleksi demokrasi karena ini adalah cara yang sah karena warga yang memilih adalah kerabat dari calon atau petahana kepala desa. Desa Menjalin sudah cukup berkembang denga segala infrastruktur yang ada wajar apabila masih menggunakan sistem kekerabatan dalam demokrasi karena rata-rata dalam satu desa adalah kerabat satu sama lain.

\section{Kesimpulan}

1. Bentuk kekerabatan Desa Menjalin dimana kekuasan Kepala Desa dipegang garis keturunan pendiri punden desa termasuk yang saat ini. Hampir disetiap RT adalah kerabat karena dalam satu desa masih ada dalam hubungan kekeluargaan kecuali warga pendatang. Jadi bisa dikatakan kekerabatan yang terdapat dalam Desa Menjalin keluarga yang luas dari keturunan ayah atau ibu atau disebut bilateral juga bisa dikatakan kekerabatan kindred dimana kesatuan kerabat yang melakukan interaksi atau berkumpul antar anggota kerabat pada

\section{Jurnal Sociopolitico}


waktu tertentu. Dalam kehidupan politik memang sudah terjadi pengkaderan dari saudara-saudara yang lebih terdahulu memimpin meskipun tidak terlihat secara masif namun sudah disiapkan untuk memimpin Desa Menjalin selanjutya.

2. Peran kerabat dalam hal ini sudah sangatlah jelas, jika sudah ada pengkaderan maka tugas kerabat yang lain pastinya gerakannya yakni menjadi tim sukses yakni mempengaruhi tetangga sekitar untuk memilih nama kerabat yang diusung dan memastikan kerabat yang diusung berhasil menduduki Menjalin satu. Karena merupakan keberhasilan serta akan menjadi orang terpandang (elit) jika kita menjadi saudara dari sebuah penguasa wilayah meskipun dalam lingkup desa.

\section{Referensi}

Arikunto, Suharsimi, 2000. Prosedur Penelitian Pendekatan Praktek. Jakarta: Rineka Cipta, Cet.XII.

Assumpta, Maria Rumanti. 2002. Dasardasar Public Relation. Jakarta: Grasindo.

Balandier, Geoges, 1996. Antropology Politik, Jakarta: PT. Raja Grafindo persada.

Bugin, Burhan, 2007. Penelitian Kualitatif; Komunikasi Ekonomi, Kebijakan Publik, dan Ilmu Sosial lainnya. Jakarta: Fajar Interpratama Offset.

Elly M, Setiadi dkk, 2010, Pengantar Sosiologi Politik, Jakarta: PT. Raja Grafindo Persada.

Holifa Nur, Skripsi Politik Dinasti (Studi Kasus Kemenangan Dinasti
Samidin Dalam Pilkades

Di Desa Banjar Kec. Kedungdung Kab. Sampang)

Kurtz, Donal V, 2001, Political Antropology "Power and Paradigms"

Westview Press, A Member Of The Perseus Books Group

Lasswell, Harold, Politic: Who Gets What, When, and How (New York:The World Publication Comp)

Mosca, Goetano, 2006. Elite dan Masyarakat. Diterjemahkan oleh Abdul Haris dan Syaid umar. Dalam T.B.Bottomore 1966, PT: Jakarta:Akbar Tandjung Institut.

Moleong, Lexy J, 2007. Metode Penelitian Kualitatif Edisi Revisi. Bandung: Rosda Karya.

Moleong, Lexy J, 2009. Metode penelitian Kuantitatif

Kualitatif.

Bandung: PT. Remaja Rosda Karya.

Rahmat, Jalaluddin, 2000. Metode Penelitian komunikasi. Bandung: PT. Rosda Karya.

Ritzer et, George. 2004. Teori Sosiologi Modern (terj). Jakarta: Prenada Media

Santoso Ananda, 2000, Kamus Lengkap Bahasa Indonesia (Surabaya:Alumni)

Surbakti, Ramlan, 2010, Memahami Ilmu Politik. Surabaya: Airlangga University.

Surbakti, Ramlan,1984. Dasar dasar Ilmu Politik. Surabaya : Airlangga University Press.

Sugiono, 2010. Metode Penelitian Kuantitatif dan Kualitatif. Alfabeta, Bandung.

Sugiono, 2010. Metode Penelitian Kuantitatif Kualitatif dan $R \& D$. Bandung, Alfabeta $\mathrm{Cv}$. 
Widjaja Haw, 1996, Pemerintahan Desa Dan Administrasi Desa, (Jakarta,PT. Raja Grafindo)

Yatim, Badri, 1993. Sejarah Peradaban Islam (Dirasah Islamiyah II), Jakarta :PT.Raja Grafindo Persada. 